
ФРАКІЦИ ДІК ПОКОЯЩИХСЯ И ГО.ОДАЮНЦИХ КЛЕТОК

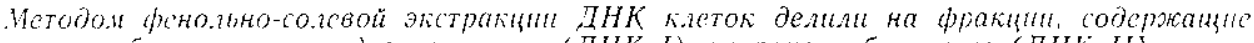

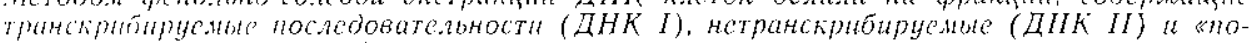
тенинаннн активнне» (ДНК

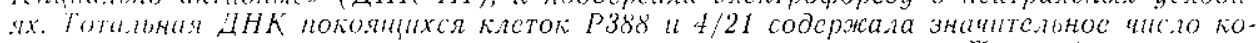

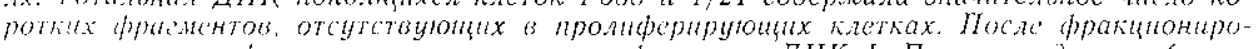

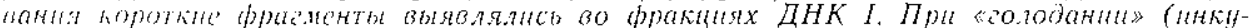

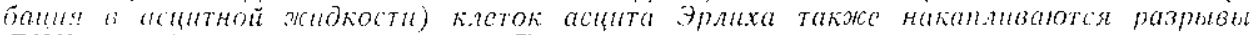

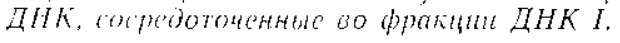

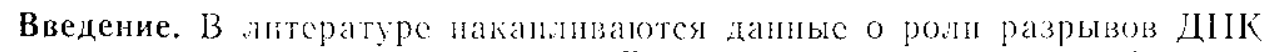

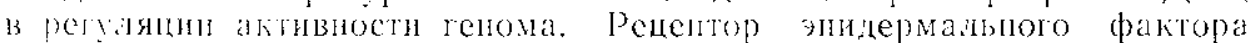

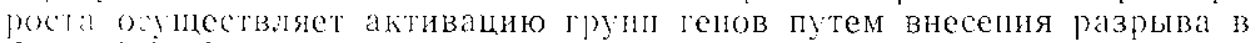

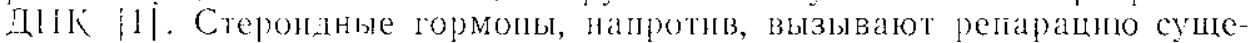

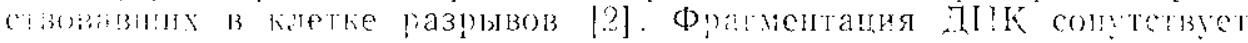

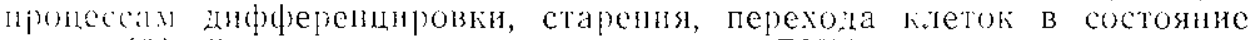

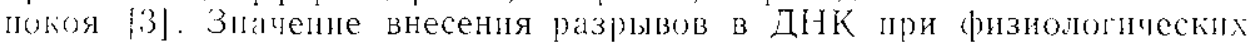

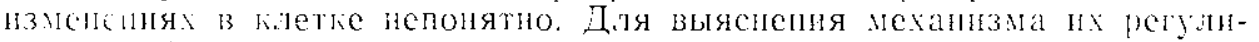

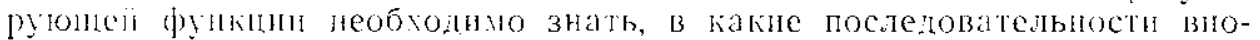

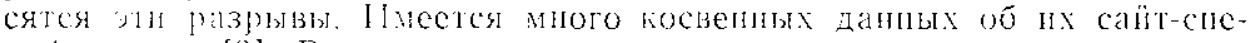

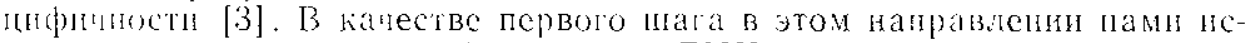

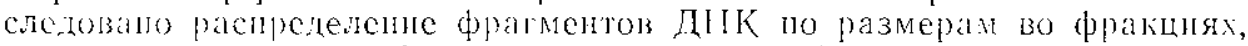

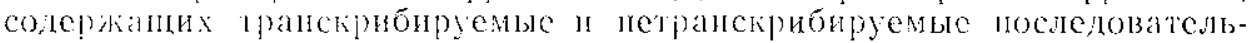

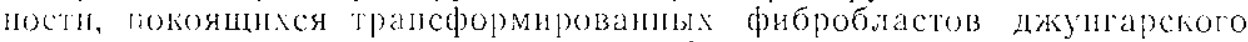

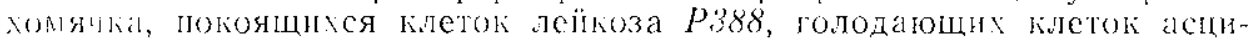

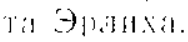

Mатериалы и методы. Трапеформированиые вирусом SVAO фиороб.тасты ижунгар-

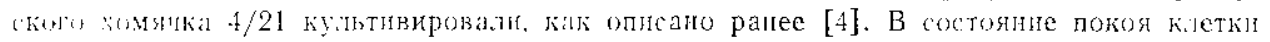

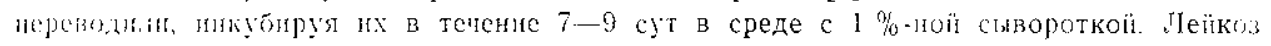

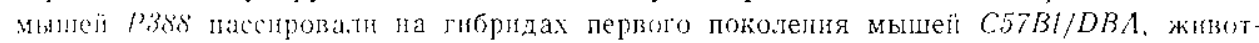

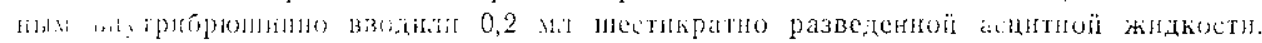

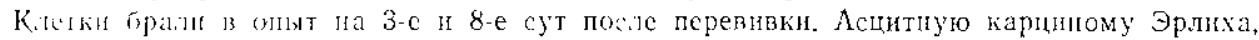

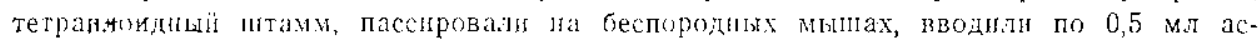
питної жидкости. На $і$-е сут животиых забизали, для получения эфф)скта гододания

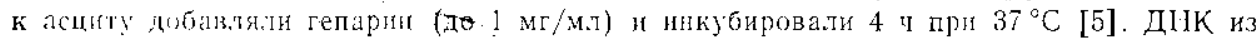
клеток пцдеия экстракцией хиороформом. Транскишинино актиные и неактивые постедов:тенинсти раздетяли методом фелольно-солевой экстракции [6, 7]. Транс-

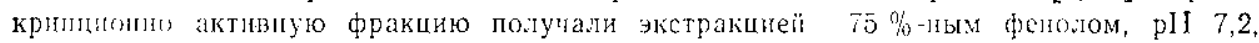

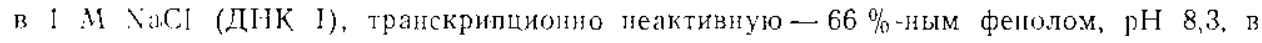

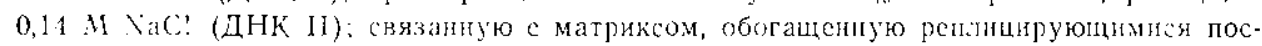

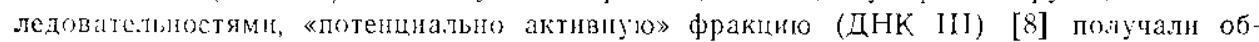
работкої нерастворимой иптерфазы посте выделения ДНK II проназой $\mathrm{P}$, DS-Na и әкетракцией хиороформом.

5.тектрофорез проводити в горнзотатыных п.тастинах в $0,7 \%$-ाом агарозном ге ле. Электрддый буфер содержал $0,04 \mathrm{M}$ трис-HCl, pH 7,9, 5 мM CH $\mathrm{COONa}_{3} 1$ мм 


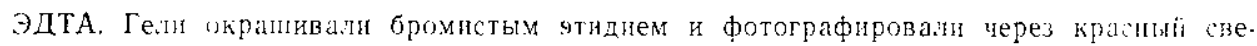

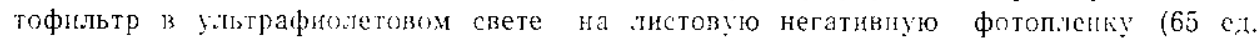
ГОСТ) прн помоци фотоувелинтеля «Беларусь-2», ІІегативы сканнровали иа денсито-

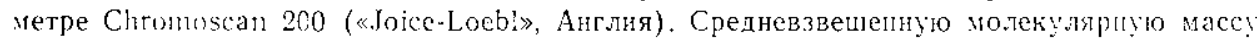

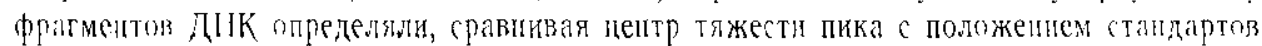
(рестрикты ДНК фага $\lambda$ рестриктазами EcoR/, PstI). Чнсло разрывоз ДНК па тысячу

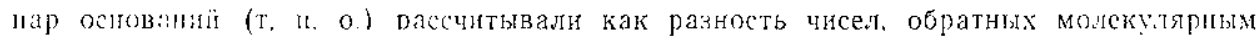

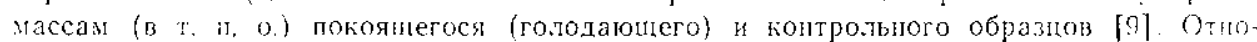

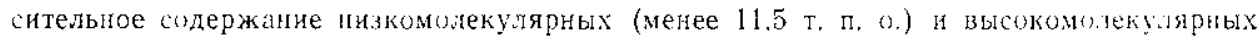
фрагментон ДНК расситынали как отношение площадеї, зак.тюненых по, пиками.

Результаты и обсуждение. В многочислспных псслсдованиях показано, тто метод фенольно-солевой экстракции позволяет разлелить трансыринионно активиые последовательности (ДІК I), ноктивные (ДНК II) и «потенциально активныс» (ДНК III) [8], При пепехо,де клеток в состояние покоя или при «голоданин» в ДНК накаплизаются одно- н двунитытыс разиывы $[3,5]$. В некоторых случаях фраглснтация ДНК пастолько заячительна, что может быть обнаружена энктро-

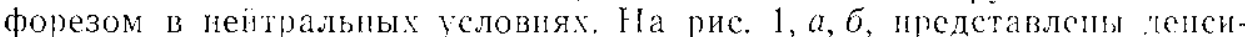
тограммы ДНК клеток лейкоза $P 388$ на 3 -е и 8 -е сут развития. К 8-џ сут клетки этой опухоли начиналт переходить в сомтояние покия, на

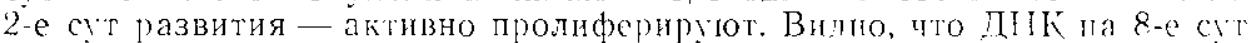
развития содержит значитсльное тнсло коротких фрагментов, которых

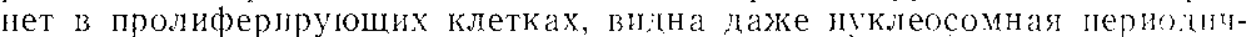
ность тасти фрагментов. Средневзвененая молекулярная масса сии-

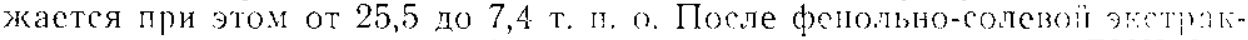

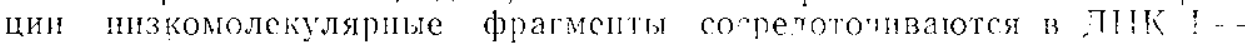
фракци, содержащей трапскриншюно активые гены (рис. 1, в- )).

При остаповке деления клеток $4 / 21$ такжс наблюдастся आнантсль-

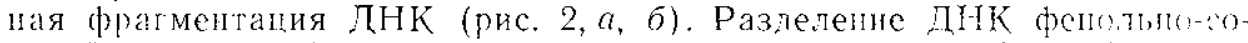
левой экстракцией показывает, что в данном случае наиболес (рагиен-

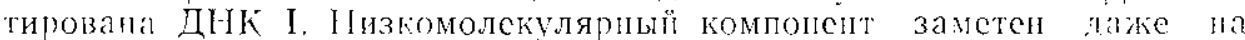
ДНК I из пролиферируоцих клеток, ДНК I покоянихся ктеток соко-

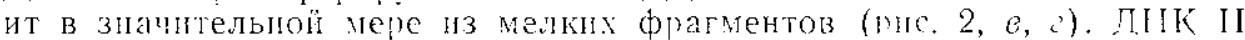
и ДНК III как нз пролифериџуюних, так и нз покояпихся клеток имеют лишь высокомолекулярный компонешт (молекулярная масса во всех случаях около 21 т. п. о., здесь не прсдставлено). Таким образом, (ракция ДНК I содержит больше разрывов и в пролиферируюших клетках, а при переходе в состояние покоя нарастание их числа илет также в транскрипцинно активноі фракции ДНК и не затрагивает ДНІ ІІ и ДНК III.

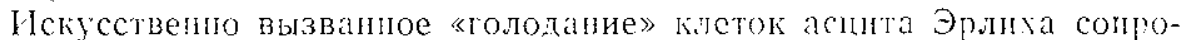
вождается налоплением разрывов ДІК га фоне активноло синтеза поли- $\mathrm{DD}$-рио́озы и па осповании этих двух критениев может рассматриваться как модель клеточной диффсрениировки $[3,5]$. На ряс. $3, a, \sigma$, приведены денстограммы тоталынй ДНК контротьных и голодаюних клеток асцита Эрлиха. Четырехчасовое «голодание» приводит к заяптельной фралмептацин ДНК, кроме уже опнсанных однонитатых разрывов, мы можем утвержғать и о иаличии твойых, так как электрофорсз проводили в нейтральных условиях. Видна зшапительпая фракщия коротких фрагментов. IІо расчет́м при голодании в тотальпую ДНК вносится примерно 0,029-0,033 разрыва на т. П. о. При фенольно-солевой экстракции фракция коротких фрагментов оказывается в ПНК І, прн сравнении размеров фрагмептов ДНК І контровиылх и голодающих клеток опредепяется $0,044-0,046$ разрыва па т. п. о. (рис. 3,0 , ?). Во фракциях ДНК II и ДНК III молекулярная масса фрагмептов ДIК контрользых н голодаюших клеток примерно одинакова (рне. $3, \partial-\ldots$ - 3 ). Такнм образом, в «голодающих» клетках асщита Эрлиха накопение разрывов ДНК отмеча́тся в транскрнгционо алтвной фракци ДНК.

Разумеется, обнарукенная нами преимушественная фрагмсптаня ДНК I еце пе означает, тто разрывы появияютея именно в транскри- 
онруемых генах. Однако в литературе кмеются указание на то, что в $\rightarrow$ кспоненциально растущих клетках фракция транскрибируемых генов, обнаруживаемая при помоши гибридизации с поли (A)*РІІК, выходит в первых фракциях при щелочной элющии, что указывает па наличие эндогенных разрывов в транскрибируемых последовате.ьыюстях [10].

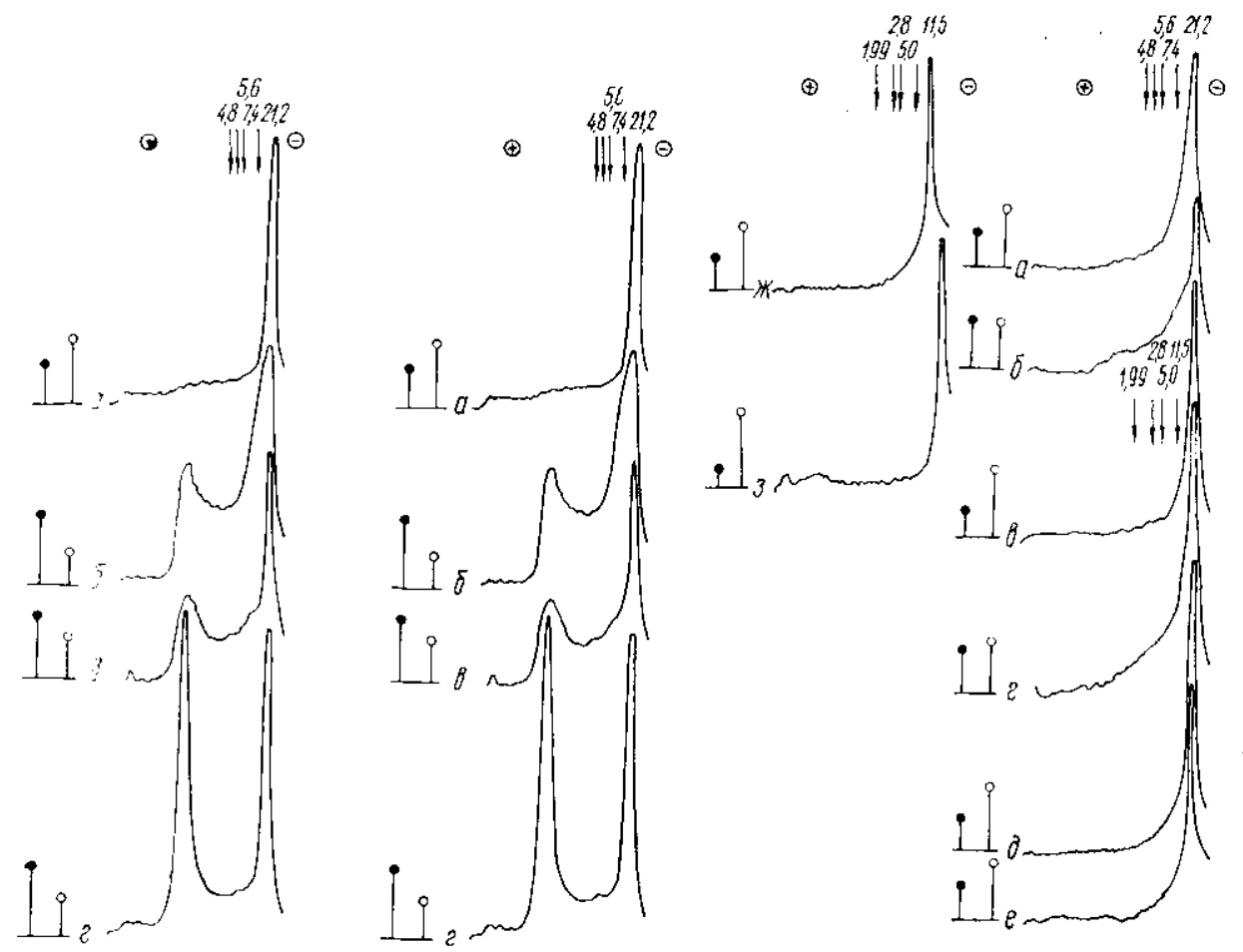

рис, 1. Элмтрофоретическое распределеше фрагмеитов ДНК, выделениых из киеток P38.: a-- к.тетки на 3-е сут развития лейкоза, тотальная ДНК; б--8-е сут развития, тотальня ILHK: $3-8$-е сут, ДНК I; 2 - 8-е сут, ДНК II; д-8-е сут, ДНК III. Стрелки обозиачают положение стандартов (т. п. о.). Стюлбнки слева от крнвых иллюстрируют относнтельное содержание ДНК с молекулярной массой менее 11,5 т. п. о. (с 'грными кружками) и с болыней молекулярной массой (с белыми кружками)

Fig. 1. Elcctrophorctical distribution of DNA fragments isolated from P388 cclis. $a-$ the $3 d$ dis of tumour development, total DNA; $\sigma$ - the 8 th day of tumour development total DNA; $a-$ the 8th day, DNAI; $a$ - the 8th day, DNAII; 2 - the 8th day, DNAIII. Arrows indicate the standard position (kbp). Columns on the left from the curves illustrate the ratio of DNA with molecular mass less than $11.5 \mathrm{kbp}$ (column with a filled circle) and with a higher molecular mass (column with an opened circle)

Pис. 2. Элсктрофоретитеское распределение фрагментов ДНК, выделіеных из клеток

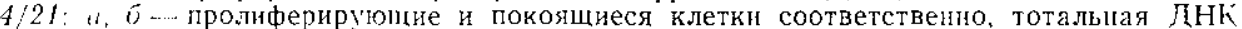

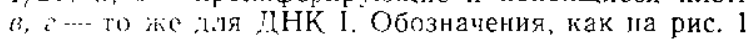

Fig. 2 Fiectrophoretical distribution of DNA fragments isolated from $1 / 21$ cells a-proliferating cells, total DNA; 6 - quiescent cells, total DNA; o-proliferating cel's, DNAI; :-quicscent cel's, DNAI. Indications as in Fig.

Рис. 3. Э.тектрофоретическое распределение фрагмеитов ДНК, вылеленых пз клетик аспита Эрінха: a, 6 - нормальные и «голодающне» клетки соответственио, тоталыная

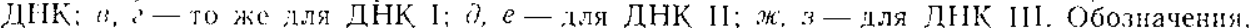
как па рис. 1

Fir. 3. E:ectrophoretical distribution of DNA fragments isolated from Ehr'ich ascite col:s: $a$ - nomal cells, tota! DNA; 6 - starving cells, total DNA; $*$ - normal cells, DNAI; - starving cells, D.NAI; $\partial$ - normal cells, DNAII; $e$ - starving cells, DNAI; w - normal cells, DNAIII; 3 - starving ce'ls, DNAIII. Indications as in Fig. 1

Шоказано усиление чувствительности гена теплового 1шока $\mathrm{k}$ специфилным для однонитчатой ДНҚ нуклеазам после его активации [11]. Таким образом, сама по себе транскрнпционная активность сопряжена с пнесением разрывов в ДНК. Возможно, что перестроїка генома в связи c перехо.дом в состояние покоя или «голоданием» требхет пнесения до- 


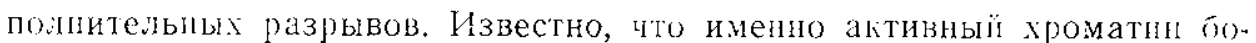
:'ее чувствителен к действию эндогенных ДІІҚаз $[12,13]$, разрывы могут вноситься этими ферментами, на что указывает наличие двойньх разрывов и нуклеосомной периоднности в некоторых препаратах. Ile нсключено, что олределенную роль во фрагментации ДНК может нг рать и топонзомераза I. Этот фермент взаимодействует с транскрибирусмыми последовательностями [14] и участвует в генерации так называемой детергент-растворимой ДНК - несвязанної с остальной массої хроматина фракции из коротких фрагментов [15], которая обогащена транскрибируемыми последовательностями [16].

Для окончательного выяснения роли разрывов ДНК в осуществлснии перестроек генома необходимо перейти к анализу отдельных генов. Наши предварительные результаты указывал на бо́льшую фрагментированность последовательностей генов тистонов по сравнению с геном актина в покояџихся клетках $4 / 21$ и голодающих клетках асцита Эрлиха. Детальное изучение этого явления составит предмет нашн дальнеїших исследованй.

\section{ACCUMULATION OF STRAND BREAKS IN DNA FRACTION CONTAINING TRANSCRIBED SEQUENCES IN QUIESCENT AND STARVING CELLS}

\section{I. Sjakste, A. V. Budylin}

Latvian Research Institute of Experimental and Clinical Mcdicinc, Ministry of Public Health of the Latvian SSR

Sum m a r y

Cellular DNA was separated in fractions containing transcribed sequences (DNAI), :111transcribed sequences (DNAII) and «potentially active» sequences (DNAIII) by meanss of phenol-salt extraction and was subjected to electrophoresis under neutral condilious. Total D.NA of quiescent $P 388$ and $4 / 21$ cells contained the great number of short frasments absent in DNA of proliferating cells. After fractionation the short fragments we :e revealed in DNAI. DNA strand breaks concentrated in DNAI fraction accumulate also in the starving (incubated in ascitic liquid) Ehrlich ascite cells.

\section{СПИСОК ЛИТЕРАТУРЫ}

1. Curpenter G. Properties of the receptor for epidermal growth factur// Cell- - 1984.37, N 2.- P. 357-358.

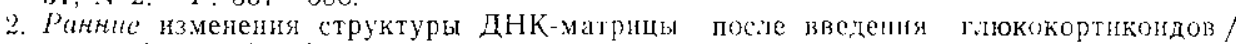
В. В. Адлер, М. А. Красилыников, Г. Ю. Бочкарев, В. С. Шапот // Бнохимия.1982 - -47, … 6. C. 915-920.

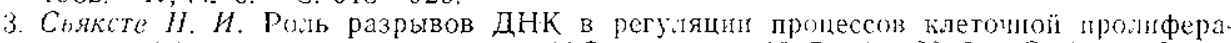
иии, дифференцировки и старелия // Oıтогелез-198і.-18, № 3.- С. 229-238.

4. Сояксте Н. И., Сиякте Т. Г. Открепление ДНК от ядерного матрикса в переведелных в состояне покоя трансформированных фибробластах джунгарского хомян-

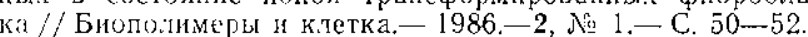

5. Stimulation of po.y(ADP-ribosyl)-ation during Lhrlich ascites tumor cell «starvationl and suppression of conconmitant $\mathrm{DNA}$ fragmentation by benzanide/ $\mathrm{K}$. Wije -

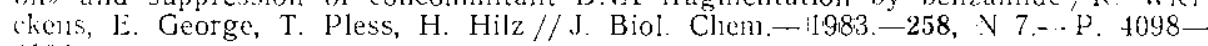
+10.4 .

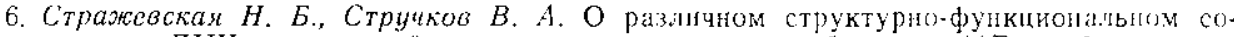
стояния ДНК в животной к.тетке в норме " пос.те обпучения// Радиобнология.-1971 -11, № 5.- C. 649-655.

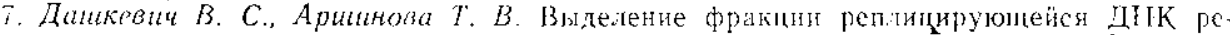
генерирующей пелени крыс бездетсргентным фенолыным методом // Изв. Сиб. отдния $\Lambda \mathrm{HI}$ CСCP. - 1973.-15, 스 3.- C. $133-135$.

8. Переход глобипювых гепов из трапскрипционо-активпой фракции ДНК во фракцио потенциалыю активюои ДНК при дифференцировке ретикулоцитов в эритро. цитах у птил / В. С. Дапкевич, А. ПТ. Қузьменко, Н. А. Скобелева и др. / Докі. AII CCCP. - 1983,-270, a. 5-C. 1236-..1238.

9. Quantitation of radiation-, chenical-, or ensme-induced sing'e-strand breaks in nonradioactive DNA by alkaline gel electroptroresis: application to pyrinidine dimers / S. E. Freeman, A. D. Blackett, D. C. Monteleone et al. //Anal. Binchenı-1986$158, \mathrm{~N} 1 .-\mathrm{P} .1119-129$

10. Induction of DNA strand breaks in transcriptionally active DNA sequences oi mouse cells by low doses of ionizing radiation /R. L. Varters, B. W Lyons, S.M. Chiu, N. L. O!einick // Mutat. Res.-1987.-180, N I.-P. 21--29. 
11. Han $S$., Udiardy $A$, Schedl $P$. Transcriptionally active chromatin is sensitive to Neurospora crassa and $S_{1}$ nucleases // J. Mol. Biol.- 1984.-179, N 3.- P. 469-496.

12. Вотрин H. Н., Ходаре' $H . H .$, Баснакиян $A$. Г. Эндонуклеазы как инструмент ис-

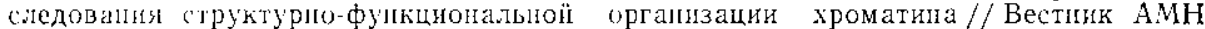
CCCP.-- 1983.- № 3. . C. $88--95$

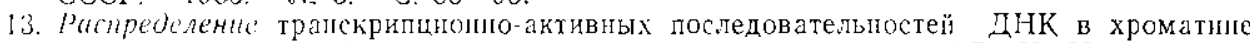
пешени крыс лри фрагментации элдогепыми нуклеазами / Г. И. Чихирджина, В. В. Бубякина, А. ПТ. Швариман, В. С. Гайпхоки // Молеку.яр. биология.- 1987.21, . $1.1 . \cdots$ C. . $125-131$.

1. Topoisomerase I interacts witls transcribed recions in Drosophila cells/D. S. GilIntsur, G. Pfluglelder, J. C. Wang, J. T. Lis // Cell- 1986.44, N 3.- P. $401-407$.

15. Rote for topoisomerases in the release of DNA into the detergent-soluble fraction uf cukaryotic cells / L. H. Zhang, S. C. Mui, J. C. Todt, P. R. Strauss // Proc. Nat. load. Sci. USA - 1986-83, N 16-P. $3871-5874$.

:6. Strauss $P, R$. Detergent soluble DNA is enriched in sequences being actively transcribed//.J. Coll. Biol-19987.-105, 'N 4, pt. 2- - P. 69a.

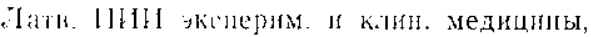

Пйіутелг 22.02 .89

Ригі́ 